\title{
The Next Tsunami? \\ Preparing for a Disorderly Correction of Global Imbalances ${ }^{1}$ \\ Barry Eichengreen \\ March 2006
}

Global imbalances and the trans-Pacific imbalance between the United States and Asia in particular loom over all discussions of the need for international policy coordination. The paradox is that, to date, the influence of these imbalances has been benign. And, in turn, the fact that the influence of the trans-Pacific imbalance has been benign has limited the perceived urgency of policy responses designed to ensure a smooth global adjustment. The United States, by running a large and persistent current account deficit, has helped to sustain the growth of global demand. China, by running a large and growing current account surplus, has helped to sustain the growth of global supply. By providing a buoyant market for the exports of other countries, the United States has facilitated the pursuit of export-led growth. It has enabled emerging markets in East Asia and elsewhere to accumulate unprecedented stocks of international reserves. By providing an elastic supply of consumer goods, China for its part has moderated global inflationary pressures and allowed the Federal Reserve System and other central banks to maintain a relatively accommodating monetary stance. To be sure, these insights are not new: the idea that global imbalances have benefits not just for the United States but also for the surplus countries is at the heart of the "global co-dependence" and "New Bretton Woods" views of the current global conjuncture (Mann 2004, Dooley, Folkerts-Landau and Garber 2003).

All this could change, of course, at a stroke. If questions arise about the sustainability of the U.S. current account deficit and the willingness of America to take steps needed to readjust its position, foreign finance for the U.S. deficit could dry up abruptly. If the U.S. capital account moves toward balance, the U.S. current account will have to move toward balance as well. The curtailment of financial inflows will mean a reduced demand for dollar assets. Lower asset valuations, including lower housing prices, will make U.S. households feel less wealthy. Who knows - they might even start saving again. As the demand for dollar-denominated assets is curtailed, the dollar exchange rate will depreciate, and higher import prices will fan imported inflation and, perhaps ultimately, force the Fed to raise policy rates further than currently anticipated.

None of this bodes well for continued economic expansion in the United States. To be sure, the more quickly a weaker dollar crowds in American exports, the moderate will be any U.S. slowdown. But even this scenario, while relatively favorable for the United States, will still not be good news for the rest of the world, since it implies a significant shift in demand away from the products of other countries.

Tonight I would like to pose the question of how policy, in Asia in particular, should be adapted in light of these risks. To be sure, there is no single definitive

\footnotetext{
${ }^{1}$ Presented to the Asian Economic Panel, Seoul, 23-24 March, and forthcoming in Asian Economic Papers. This presentation draws on work the author has done for the Asian Development Bank and on an ongoing collaboration with Yung Chul Park, whose input is acknowledged with thanks.
} 
interpretation of the trans-Pacific imbalance, and a number of influential accounts raise doubts about the risk of a disorderly correction. But the absence of a consensus is not a justification for inaction by policy makers. There may similarly be no consensus about the likelihood of another Asian tsunami, but this does not relieve policy makers of the need to prepare - and for them to buy insurance against the possibility. There is an analogous argument for preparing for the possibility of a disorderly correction of the U.S. current account.

Doing so requires identifying how Asian economies will feel the effects of a disorderly correction. My argument is that, in contrast to earlier periods characterized by rising U.S. interest rates and sudden stops in capital flows, this time it is unlikely to be financial channels through which emerging Asian countries are primarily affected. Asian countries are running current account surpluses instead of deficits and minimizing their borrowing. Stronger policies have reduced the danger of capital flight. They have accumulated immense amounts of reserves in the effort to financially bullet proof their economies. This is not to suggest that the financial consequences of a disorderly correction of the U.S. deficit will be painless. In particular, the exceptionally low interest rates on sovereign bonds and flood of foreign money into local stock markets will not persist in this scenario, and a sharp adjustment in asset prices will not be easy to digest. Still, there is less reason for East Asia to worry about the financial fallout than on prior occasions when there occurred sharp increases in U.S. interests. ${ }^{2}$ Note that this is quite different than the situation in, say, Latin America. ${ }^{3}$

Rather, the principal risk to the emerging Asian economies lies in the possibility that a disorderly correction could precipitate a major slowdown in U.S. growth and, in particular, in the growth of U.S. net import demand. In this scenario, the unavoidable consequence would be very sharp compression of U.S. and global demand. If capital inflows into the United States decline by $6 \frac{1}{2}$ per cent of GDP (their current level) because foreign finance dries up completely, then the current account must move immediately to balance by the definition of the balance of payments. The result on impact would be for U.S. demand and specifically U.S. net demand for imports to decline by $6 \frac{1}{2}$ per cent. Assuming a world economy growing at 5 per cent and a U.S. economy that accounts for a quarter of the world, this eliminates more than a third of the normal growth in global demand. And, of course, the second-round effects following on this fall in production could then aggravate the impact on output and employment. For the world as a whole, this could be a major recessionary event.

Exposure to the danger of a disorderly correction is thus greatest for countries that are highly open and export heavily to the United States. In data for 2004, this share varies from a high of 25 per cent in the small highly-open East Asian economies (Hong Kong, Singapore and Taiwan) to a low of 3 per cent in the euro area and Japan. ${ }^{4}$ In

\footnotetext{
${ }^{2}$ Note the reference here to East Asia. Countries like India with large current account deficits and relatively small amounts of inward FDI have more reason to worry.

${ }^{3}$ Or in Hungary and Turkey. But that is the subject of a different paper (Eichengreen and Park 2006).

${ }^{4}$ We should probably discount the very high figures for these three countries at least to some extent because of the low domestic content of many of their exports.
} 
between one finds the Anglo Saxon economies (Australia, Canada, New Zealand and the United Kingdom), the larger East Asian economies (Indonesia, Malaysia, the Philippines, South Korea and Thailand) and China toward the high end, at 8-9 per cent and Latin America at the low end at 4 per cent. Looking at the issue comparatively, East Asia is more vulnerable than Latin America mainly because the Asian region is more open and not inconsiderably linked to the United States. ${ }^{5}$

How should Asian policy makers respond to these risks? In my view the appropriate policy package has six components.

- First, Asian currencies should be allowed to begin appreciating against the dollar now in order to narrow current account surpluses vis-à-vis the United States and thereby reduce the region's exposure to a sudden compression in the U.S. deficit. Movement toward greater exchange rate flexibility now, before re-balancing pressures mount further, would minimize confidence problems and give authorities greater monetary flexibility, which is precisely what the need.

- Second, progress in regional trade liberalization should be urgently accelerated. This will limit the need to radically restructure production away from exports and allow Asian economies to continue exploiting their comparative advantage.

- Third, offsetting the contractionary impact on demand of currency-appreciationcum-monetary-tightening will require in addition domestic policies of fiscal stimulus. ${ }^{6}$ (Note that trade liberalization initiatives by themselves will not be enough because they will not affect the overall level of demand.) Caveats are relevant here as always. Fiscal loosening should be carefully considered on a case-by-case basis in the context of well-defined expenditure programs that address priority areas, sound public expenditure management practices and appropriate recognition of contingent liability and debt sustainability issues. I am clearly not recommending sharp fiscal expansion in Indonesia or the Philippines, in other words. That said, maintaining an appropriate level of demand in the face of currency appreciation and monetary tightening will require some expansionary thrust from fiscal policy across the region as a whole. Here Korea has shown the way. China, among others, should follow.

- Fourth, measures promoting financial market development can also help by relaxing credit constraints and reducing the incentive for high levels of precautionary saving. This will eventually work to address the region's savingsinvestment imbalance. That said, these initiatives work over a relatively long horizon and are thus be less helpful for offsetting a disorderly correction of the trans-Pacific imbalance in the scenario where this occurs relatively soon. Indeed, focusing on such long-term measures alone may increase the risk of disruptive effects when the adjustment occurs. Note also that this perspective on financial

\footnotetext{
${ }^{5}$ One would want to make an exception for countries like Mexico, of course, which are exceptionally dependent on exports to the United States.

${ }^{6}$ This case has been influentially made by Blanchard and Giavazzi (2005).
} 
development and integration is also quite different from the conventional Asian emphasis on the desirability of deepening regional financial markets in order to better "recycle Asian savings within the region." At present, capital flows out from Asia to the United States in the form of investment in U.S. treasury securities and then back to Asia (especially China) in the form of U.S. FDI. Instead channeling the same amount of money directly from Chinese savers to Chinese investors will not change anything relevant to the current account. In other words, attempting to divert Asian savings from the U.S. to the region will, by itself, have no significant impact on global imbalances or the risk of a disorderly correction.

- Fifth, there is a need for flexibility in intra-Asian exchange rates, given that the impact of the shock and policy makers' room for maneuver will differ across countries. In particular, since both the impact of a U.S. slowdown and the scope for compensatory policies differ across countries, so too does the need for currency adjustments. The argument that Asian currencies will have to appreciate as a group against the dollar is valid, but it is not an argument for suppressing intra-regional currency movements. Attempting to lock diverse Asian countries into a single exchange rate straitjacket is a recipe for suppressing adjustment.

- Sixth, and notwithstanding he immediately preceding caveats, adjustments can be undertaken more easily and will be more effective if they are coordinated across countries. Within Asia this means reaching agreement on the desirability of stronger currencies against the dollar and of fiscal stimulus, since in both cases there are first-mover and free-rider problems. It means redoubling efforts to complete an Asian free trade area and cooperating on financial development. It means negotiating an agreement on reserve transparency to facilitate the orderly diversification of foreign reserves and to minimize the risk of destabilizing portfolio shifts. It means building stronger and more independence institutions of regional surveillance to facilitate collective assessment of economic conditions, risks, and vulnerabilities.

We could talk at considerably greater length about every one of these issues, but the hour is late and the day has been long. However, I do feel compelled to reiterate one point, that one doesn't have believe that a disorderly correction is inevitable to justify taking steps to prepare for the possibility. For China this means moving away from an excessive dependence on exports to the United States by modifying the macroeconomic policy mix in the direction of looser fiscal and tighter monetary policies. ${ }^{7}$ Given the difficulty of changing the composition of demand in short order and, in particular, coordinating increases in public spending between the central and provincial governments, this means initiating the adjustment even while the trans-

\footnotetext{
${ }^{7}$ Here "tighter monetary policy" is synonymous with allowing the renminbi to appreciate more rapidly against the dollar.
} 
Pacific imbalance persists. ${ }^{8}$ Given that the benefits of fiscal stimulus spill across countries, especially neighboring Asian countries increasingly linked by vertical intra-industry trade and direct foreign investment, this means internalizing these externalities by coordinating policy. The same argument applies to exchange rate adjustments, where individual Asian countries are understandably reluctant to move without the support of their neighbors. The same argument again applies to accelerating the process of regional trade liberalization. The case for policy coordination is compelling. And the time to start moving is now.

Thank you for your attention.

\footnotetext{
${ }^{8}$ And, indeed, continues to grow if recent data releases in the United States are any indication. Recent indications that the Chinese authorities are prepared to take steps to boost spending on rural infrastructure are reassuring in this light.
} 


\section{References}

Blanchard, Olivier and Francesco Giavazzi (2005), "China: A Three Handed Approach," unpublished manuscript, MIT.

Dooley, Michael, David Folkerts-Landau and Peter Garber (2003), “An Essay on the Revived Bretton Woods System,” NBER Working Paper no. 9971 (September).

Eichengreen, Barry (2004), "Global Imbalances and the Lessons of Bretton Woods,”NBER Working Paper no.10497 (May).

Eichengreen, Barry and Yung Chul Park (2006), "Global Imbalances and Emerging Markets," paper presented to the Fondad conference of the same title, the Hague, 27-28 February.

Mann, Catherine (2004), "Managing Exchange Rates: Achievement of Global ReBalancing or Evidence of Global Co-Dependence?" unpublished manuscript, Institute for International Economics (July). 